\title{
The composition of the aphid fauna of Fennoscandia and Denmark
}

\author{
Ole E. Heie
}

Heie, O. E. 1995: The composition of the aphid fauna of Fennoscandia and Denmark. - Entomol. Fennica 6:119-121.

\begin{abstract}
A systematic, zoogeographical and ecological survey of the composition of the aphid faunas of Norway, Finland, Sweden and Denmark is given. A total of 634 species have been recorded, most of them of western Palearctic origin. Some species have their borders of distribution here, in several cases depending on the distribution of host plants. Some of the species are boreo-alpine and some others have recently been introduced from other continents.
\end{abstract}

Ole E. Heie, Department of Biology, DLH, Emdrupvej 101, DK 2400 Copenhagen NV, Denmark

\section{Introduction}

The aphids are divided into two superfamilies, Phylloxeroidea and Aphidoidea. The species of Phylloxeroidea have not developed siphuncular pores, and all generations are oviparous. The Scandinavian fauna consists of about twenty species, probably 18 . They belong to two families, Adelgidae on coniferous trees, where some of them make cone-like galls on Picea, and Phylloxeridae on broadleaved woody plants, the best known of which produces small yellow spots on leaves of oak.

The superfamily Aphidoidea is much richer in species. In "Fauna Entomologica Scandinavica" keys and descriptions of 616 Scandinavian species and several species occurring in West, Central and East Europe outside the Scandinavian countries are given (Heie 1980, 1982, 1986, 1992, 1994 and in press). They have opposite to Phylloxeroidea siphunculi or siphuncular pores, in some cases reduced, and the partheno- genetic generations are viviparous. Only the sexual female, the female demanding fertilization before reproduction and appearing in the last generation of the year, is oviparous.

The publication of the volumes mentioned above has only been possible on the basis of cooperation by several aphid specialists, partly people from countries outside Scandinavia, partly by Scandinavian colleagues. Among the Scandinavian scientists engaged in aphid systematics and faunistics can be mentioned the Swedes Carl von Linné, DeGeer, Zetterstedt, Tullgren, E. Wahlgren, F. Ossiannilsson, Jan Pettersson and Roy Danielsson, the Norwegians J. Fjelddalen, Chr. Stenseth and Helene Tambs-Lyche, the Finns E. Thuneberg, Osmo Heikinheimo and A. Albrecht, and the Danes J. C. Fabricius and J. E. V. Boas. The distribution of species in Norway has mainly been studied by the late Helene Tambs-Lyche, in Sweden by Ossiannilsson and Danielsson, in Finland by Heikinheimo and Albrecht and in Denmark by myself. 


\section{Species richness compared with the number of species in the world.}

The worldwide number of described aphid species 4425 . New species are described every year, and the total number may soon be over 5 000. In Finland, Norway, Sweden and Denmark 634 species have been found, and the real number may be about 680 . Accordingly, the Scandinavian fauna contains $14-15 \%$ of the world fauna. This is a large percentage compared to the size of the area and also large compared to most other insect groups, which are richer in species in the tropics than in the temperate regions.

How can this difference be explained? Certainly many kinds of landscapes and plant societies and areas with different climate (temperate vs. arctic, oceanic vs. continental), occur here, but the number of plant species is considerably smaller than in areas of the same size in the tropics, and an aphid species frequently feeds on only one plant genus.

Fossil aphids from the Baltic amber and other deposits from the Lower Tertiary mainly belong to groups, which today occur as native forms of all parts of the world, including the tropics, while the families richest in species today were little represented in the Lower Tertiary and became rich in species much later, when the climate became colder. They speciated on the northern hemisphere, where large areas became grassland, and did not pass the tropics, which acted as a barrier for two reasons (Heie 1994a): The new species were 1) adapted to a climate with large differences between summer and winter, and most of them were 2) associated with a single plant species or genus. The species diversity of plants is large in the tropics, which means that the chance of a winged aphid for landing on a host plant is very small, when it leaves the plant, on which it was born (Dixon et al. 1987).

As the tropical region is a barrier, and as evolution and speciation mainly took place (and still takes place) on the northern hemisphere, not only the tropics, but also the subtropical and temperate areas on the southern hemisphere have few native aphids. In these areas, most species have been introduced by man.

\section{Origin of the Scandinavian fauna.}

The following survey deals with the 616 species of Aphidoidea only. Most of them, about $90 \%$ (about 550 species), have probably evolved in the Palearctic region; $90 \%$ of them (about 490 species) are western Palearctic. It is, however, difficult to give exact information because aphids are easily spread by wind or humans. Many Scandinavian species are currantly distributed in the main part of Europe and Asia; probably only about 15 species are of East Asian origin. About 20 species are of Mediterranean origin; 21 species are known only from Scandinavia; about 20 species are arctic or boreo-alpine. The latter occur in two separate areas, the Arctic region, viz. the northern part of Fennoscandia and in some cases also Greenland and the Alpine region, e.g. Calaphis arctica Hille Ris Lambers. The populations in Central Europe seem to be morphologically somewhat different from the populations in Greenland, but samples from Finland are more similar to the samples from Central Europe than to samples from Greenland.

Five species show a north-western distribution and may be called oceanic, while a much larger number, 27 species, have their main distribution in East Europe or West and Central Asia and may be called continental.

Several Scandinavian species have a Holarctic distribution, but in most cases these species were originally either Palearctic or Nearctic. They have been introduced into North America from Europe or vice versa. About 15 Scandinavian species have been introduced from North America, one or two from South America. This introduction occurred primarily by plants on ships, but today also transport by aircraft happens. A Central Asian aphid on Impatiens parviflora (Impatientinum asiaticum Nevsky) appeared around airports in East Europe in the end of the sixties (Holman 1971). After that it has spread to other parts of Europe, including Denmark, Sweden and Finland.

\section{Distribution in Scandinavia.}

The number of species decreases of course from 
south to north; about $83 \%$ of the aphid species have been found in Denmark and southern Sweden, only $14 \%$ north of the polar circle; $12 \%$ occur in Denmark and southern Sweden exclusively, only $1.5 \%$ exclusively north of the polar circle.

In Denmark $73 \%$ of the aphid species have been found, in Sweden $88 \%$, in Norway $51 \%$ and in Finland $68 \%$. A little more than one-third have been found in all four countries.

Most species have been recorded from the lowland opposite to the condition in other parts of the world, e.g. USA and Central Europe, where mountains are richest in species.

\section{Association with host plants.}

Among species of Aphidoidea $17 \%$ are hostalternating; $29 \%$ feed on woody plants only, $56 \%$ on herbaceous plants only, and $15 \%$ both on woody plants and herbs. It is amazing that many species feed on only a single plant genus, $64 \%$.

Among the host plants $93 \%$ are angiosperms and $7 \%$ not, in most cases conifers and in a few cases spore plants (mosses, horsetails and ferns).

The distribution of an aphid species usually equals the distribution of its host plant. An aphid species is common if its host is common. There are, however, exceptions. Most species on the rather common plant Artemisia campestris are rare. Geum is common in the main part of Scandinavia, and this plant has two aphids, a common one and a rare one. An aphid with host alternation between Prunus mahaleb and Lythrum salicaria (Myzus lythri (Schrank)) is rather common though its primary host is not.

Some aphids apparently have a northern border south of the northern border of their host plants, e.g. one on Tragopogon (Brachycaudus tragopogonis (Kaltenbach)) and one on Rubus spp. of the fruticosus-group (Macrosiphum funestum (Macchiati)).

\section{Life cycles.}

$92 \%$ of the Scandinavian species are holocyclic. This means that they have a sexual generation and overwintering by fertilized diapause eggs. About $8 \%$ are exclusively anholocyclic, which means that all generations are parthenogenetic, and overwintering takes place as parthenogenetic females and their offspring. Some of the holocyclic species can overwinter as parthenogenetic females, too, e.g. the green peach aphid (Myzus persicae (Sulzer)). In the tropics they may be exclusively anholocyclic.

This situation can be compared with the situation in two other areas, Cuba in the tropics and Australia on the southern hemisphere. Only 23\% of the aphids in Cuba are holocyclic, but they are only so in temperate regions outside Cuba. In Cuba they are anholocyclic, and host alternation does not occur. Only a few species are native to the Caribbean region; $88 \%$ have been introduced by man, mostly from North America, Europe and Asia, only a few from South America. Many are polyphagous, only $33 \%$ associated with a single plant genus, only about half of the percentage in Scandinavia.

Only 119 species have been found in Australia. The number of holocyclic species is unknown, but at least six of them have host alternation. Most are introduced from other continents, $87 \%$, and many are anholocyclic and polyphagous. Only $37 \%$ are apparently associated with a single plant genus.

\section{References}

Dixon, A. F. G., Kindlmann, P., Leps, J. \& Holman, J., 1987: Why are there so few species of aphids, especially in the tropics? - Am. Nat. 129: 580-592.

Heie, O. E., 1980-1994. The Aphidoidea (Hemiptera) of Fennoscandia and Denmark. I-V. - Fauna Entomol. Scand. 9, 11, 17, 25 and 28. Scandinavian Science Press and Brill.

- 1994a: Why are there so few aphid species in the temperate areas of the southern hemisphere? - Eur. J. Entomol. 91: 127-133.

— in press. The Aphidoidea (Hemiptera) of Fennoscandia and Denmark. VI. - Fauna Entomol. Scand. Brill, Leiden.

Holman, J., 1971: Taxonomy and ecology of Impatientinum asiaticum Nevsky, an aphid species recently introduced to Europe (Homoptera, Aphididae). - Acta Entomol. Bohemoslov. 68: 153-166. 